\title{
Viruses and lymphocytes in rheumatoid arthritis. II. Examination of lymphocytes and sera from patients with rheumatoid arthritis for evidence of retrovirus infection
}

\author{
HELENA HART ${ }^{1}$, J. N. MCCORMICK ${ }^{2}$, AND B. P. MARMION 1 \\ From the ${ }^{1}$ Department of Bacteriology, University of Edinburgh, and the ${ }^{2}$ Rheumatic Diseases Unit, Northern \\ General Hospital, Edinburgh
}

SUMMARY The possible involvement of retroviruses in the aetiology of rheumatoid arthritis (RA) $\stackrel{\cup}{A}$ was investigated. Retrovirus antigens were not expressed on rheumatoid synovial and peripheral 을 blood lymphocytes as judged by membrane immunofluorescence, radioimmunoassay, and comple- $-\overrightarrow{-}$ ment-mediated cytotoxicity. The specific antiretroviral (anti-RD-144 and anti-SSAV) sera used in $\mathbb{D}$ this study were produced in rabbits immunised with viral antigens grown in a homologous system $\Phi$ (rabbit cells and medium supplemented with normal rabbit serum), avoiding non-specific immuno- $\frac{\Xi}{0}$ fluorescence previously detected with donated antiretroviral sera. Immune complexes lodged in the rheumatoid synovial membranes did not contain, and other cells within the membranes did n@ी $\vec{\oplus}$ express, retroviral antigens. Antibodies cross-reacting with primate retrovirus antigens were sough ${ }^{\circ}$ in sera from patients with 'autoimmune' diseases by means of solid phase radioimmunoassay. The were no retrovirus antibodies in the 3 groups of patients studied, that is, those with rheumatoid arthritis, systemic lupus erythematosus, and with non-RA conditions. Absorption of rheumatoid factor did not alter this conclusion. These results give little support to the hypothesis that activation of endogenous human retroviruses or an infection with horizontally transmitted retroviruses is associated with the rheumatoid process.

Background information on the possible role of viruses in rheumatoid arthritis (RA) is reviewed briefly in the accompanying paper (Norval et al., 1979) and by Marmion (in press). Their role in other autoimmune disease has been considered by Denman (1975) and by various authors in Tatal (1978). Notably, in systemic lupus erythematosus (SLE) antigens reactive with antisera specific to the proteins of mammalian retroviruses have been detected in the kidneys (Mellors and Mellors, 1975; Panem et al., 1976).

Interest has been reawakened recently by a paper from Phillips et al. (1978), who isolated a retrovirus from SLE placenta 9 months after fusion with permissive cells. This contrasts with previous negative isolation attempts (Phillips et al., 1976; Phillips and

Accepted for publication 19 December 1978.

Correspondence to Dr Helena Hart, Department of Bacteriology, University of Edinburgh Medical School, Teviot Place, Edinburgh EH8 9AG.
Hargrave-Granda, 1978). Particles resembling retroviruses have been seen in placentas of SLE ? patients at a higher frequency then normal placentas (Imamura et al., 1976) but have not been observed in the diseased organs (e.g., spleen and kidney). In addition RNA-dependent DNA polymerase has not been found in cultures of SLE tissues (Phillips and 9 Hargrave-Granda, 1978).

In analogous studies RA extracts of synovial membranes on the one hand, or cultured or co- N cultivated synovial cells on the other, were not shown to contain viral polymerases (Spruance et al., 1975; Norval et al., 1975). Less attention has been $\omega$ paid in studies of RA to the possible involvement of retrovirus with cells of the immune and immunore- $O$ gulatory system. The present study complements that on cultured lymphocytes (Norval et al., 1979) by $\stackrel{?}{\rightarrow}$ attempting to detect retrovirus antigens on $\underline{T}$ rheumatoid synovial fluid lymphocytes and $\stackrel{\circ}{\mathbb{D}}$ peripheral blood lymphocytes of RA patients. A 
search was also made for the retrovirus antigens in sections of rheumatoid synovial membranes, thus taking into account other immunoregulatory cells within the perivascular region in synovial membranes.

Other evidence on the involvement of retroviruses in 'autoimmune' diseases would be provided by the detection of an increased level of specific antimammalian retrovirus antibodies in the patient's sera. Several laboratories have reported the presence in sera from healthy persons of antibodies that react with proteins of primate retroviruses (Synder et al., 1976; Aoki, et al. 1976; Metzgar et al., 1976; Kurth et al., 1977); however, others have failed to find such antibodies (Charman et al., 1975; Prochownik and Kirstein, 1976; Stephenson and Aaronson, 1976).

Retroviruses so far isolated from human tissues have been shown to be a mixture of 2 viruses, one closely related to simian sarcoma-associated virus (SSAV) and the other to the M7 strain of baboon endogenous virus (BEV) (Gallagher and Gallo, 1975); the latter is closely related to the endogenous feline virus RD-114 (Todaro et al., 1974).

The present paper deals with the examination of sera from RA and SLE patients for antibodies to the RD-114 virus grown in RD cells and SSAV grown in KNRK cells, and with tests of synovial and peripheral blood lymphocytes for membrane antigens related to these two mammalian, primate-related retroviruses.

\section{Materials and methods}

Lymphocytes. Synovial fluids were treated with $80 \mathrm{U} / \mathrm{ml}$ of hyaluronidase for $30 \mathrm{~min}$ at $37^{\circ} \mathrm{C}$ before separation of mononuclear cells on Ficoll-Triosil gradients (Harris, 1970) while the defibrinated peripheral blood was used directly. The lymphocyterich fraction was washed twice in Hanks's salt solution and incubated in 199 medium containing $100 \mu \mathrm{g} / \mathrm{ml}$ of streptomycin and $100 \mathrm{I} \mathrm{U} / \mathrm{ml}$ of penicillin supplemented with $20 \%$ pooled human serum (designated 'cultured lymphocytes'). Half of synovial fluid lymphocytes from each specimen were also trypsinised by the method of Wangel and Klockars (1977) ('trypsinised and cultured lymphocytes'). For cytotoxicity tests the lymphocytes were suspended in 199 medium supplemented with $10 \%$ inactivated pooled human serum. The method of Abrahamsen et al. (1975) was used to obtain lymphocytes from synovial membranes.

Serum specimens. Human sera were divided into 3 groups: Group I, sera from RA patients; of these all were positive for rheumatoid factor (RF), 5 showed antinuclear factor (ANF), 2 were negative for ANF and 3 were not tested. Group II, sera from a non-RA group; 5 patients with osteoarthrosis (OA), 3 tennis elbow cases, 1 polymyalgia rheumatica, and 1 primary generalised osteoarthrosis (PGOA). None was positive for either RF or ANF. Group III, sera from 11 SLE patients, all of whom had a positive ANF test and a negative RF test.

Before use all sera, including positive rabbit control sera, were absorbed with human (group AB) and sheep red blood cells and acetone-dried human liver powder.

The effect of the removal of RF was also investigated. RF was adsorbed with insolubilised Cohn fraction II; $1 \mathrm{~g}$ of normal human gammaglobulin was solidified in $5 \mathrm{ml}$ of $\mathrm{PBS}$ at $75^{\circ} \mathrm{C}$ for $15 \mathrm{~min} .40 \mathrm{mg}$ of the washed gammaglobulin precipitate was mixed with $1 / 10$ dilution of RA sera and removed by centrifugation $(400 \mathrm{~g}, 10 \mathrm{~min})$ after $30 \mathrm{~min}$ of stirring. Each serum was absorbed till completely negative in a slide latex test; usually 3 consecutive absorptions were needed.

\section{CELL LINES WITH RETROVIRUSES}

$R D-114$ virus infected $R D$ cells (human rhabdosarcoma cell line, originally isolated by McAllister et al. (1971) and described by McAllister et al. (1972) ) were kindly donated by $\operatorname{Dr} \mathrm{N}$. Teich, Imperial Cancer Research Fund Laboratories, London. Uninfected control RD cells were obtained from Dr O. Jarrett.

RD-114 RD cells and RD cells were split twice a week (Earles based Eagles medium with $5 \%$ FCS). To adapt the RD-114 virus to $\mathrm{RK}_{13}$ cells as a preliminary to producing antigen to immunise rabbits UVirradiated RD-114 infected RD-cells (Rowe et al., 1970) were cocultivated with DEAE dextran $(25 \mu \mathrm{g} / \mathrm{ml})$ treated rabbit kidney $\mathbf{R K}_{13}$ cells. The resulting cultures-control $R K_{13}$ and $R D-114$ $\mathrm{RK}_{13}$-were grown in 199 medium supplemented with $5 \%$ normal rabbit serum. The continuous production of RD-114 virions, which appeared 6 weeks after cocultivation, was checked by labelling with $\left(5-{ }^{3} \mathrm{H}\right)$-uridine and by reverse transcriptase assay (Norval and Marmion, 1976). The possibility that the RK $_{13}$ cells had been overgrown by RD-114 infected RD cells was excluded by testing for the lactic dehydrogenase isoenzymes (Seck et al., 1970). The isoenzyme patterns were those of the $\mathbf{R K}_{13}$ cells and not those of the human rhabdosarcoma cell line.

Simian sarcoma-associated helper virus (SSAV), kindly donated by $\mathrm{Dr} \mathrm{N}$. Teich, was propagated in a rat kidney cell line originally transformed by Kirstein strain murine sarcoma virus (KNRK). KNRK cells do not produce infectious particles (Stephenson et al., 1972). The SSAV infected KNRK cell line was called KW23.

Simian sarcoma-associated helper virus producing 
cell line (KW23) and control rat kidney (KNRK) were also split twice a week (EE medium, supplemented with $5 \%$ FCS). For the preparation of antigen to immunise rabbits the cell lines were propagated in medium with normal rabbit serum (5\%).

Membrane immunofluorescence test for viral antigens was carried out as described by Yoshiki et al. (1974). Viral antisera: goat anti-RD-114, against Tween-either disrupted (TED) virions; goat anti-Moloney leukaemia virus (TED); goat antiwoolly monkey fibrosarcoma, SSAV-1 (TED); goat anti-feline leukaemia against proteins, p12 and p28; goat anti-Mason Pfizer mammary virus (MPMV), p12 and p28; all kindly supplied by Dr J. Gruber from the National Cancer Institute, Bethesda. Additional viral antisera obtained (batch 2) included: anti-RD-114 p28, anti-baboon, C-type (TED), and anti-baboon, C-type p28.

The goat antisera were used at $1 / 5$ dilution in phosphate buffered saline, $\mathrm{pH} 7 \cdot 2$, supplemented with $2 \%$ inactivated FCS. The lymphocyte-rich cell fraction after an overnight incubation was used at a concentration of $10^{7} / \mathrm{ml}$. Anti-goat IgG conjugated with fluorescein isothiocyanate purchased from Nordic Diagnostics and used at 1/10 dilution for the indirect immunofluorescence. All the NCI goat antiviral sera were found to have rheumatoidfactor-like activity at a dilution of $1 / 5$ to $1 / 100$ by agglutination of human serum-coated sheep blood cells. They were therefore absorbed with human serum-coated, glutaldehyde-fixed sheep blood cells (Avrameas et al., 1969). The sera were negative for antinuclear factor (ANF). Control sera included normal goat serum and, as a control for the immunisation process, goat anti-Mycoplasma fermentans serum (Robins Lab., NY).

Additional anti-RD-114 and anti-SSAV sera were produced in rabbits using Tween-either disrupted, sucrose gradient purified (Norval and Marmion, 1976) viral particles grown in $R_{13}$ and $K N R K$ cells, respectively (antiviral sera). Simultaneously, as a control, other rabbits were infected with purified fractions from uninfected $\mathrm{RK}_{13}$ or $\mathrm{KNRK}$ cells (anticell sera).

For immunisation $\mathbf{0 . 2} \mathrm{mg}$ of viral protein was mixed with incomplete Freund's adjuvant and injected subcutaneously at weekly intervals (4 times). Antibody titre was further boosted with alum $\left(\mathrm{Al}_{2} \mathrm{O}_{3}\right.$, Seranac $\mathrm{Ltd}$.) precipitated antigen given intravenously (twice). Both antiviral sera were used when a titre of 320 was reached, as measured by immunofluorescence on acetone fixed coverslips of RD-114 RD and KW23 cells. (The anti-SSAV serum showed specific viral antibody at a dilution of $1 / 320$ after only 3 absorptions with $0.1 \mathrm{mg}$ of acetone dried rat liver powder/ml at 1/80.) Anti-RD- 0 114 and control sera are designiated R34/RD-114 $\mathrm{RK}_{13} / 6-29.8 .77$ and $\mathrm{R33} / \mathrm{RK}_{13} / 6-29.8 .77$ and anti- $\vec{\Rightarrow}$ SSAV and control sera are R42/KW23/4-9.12.77 and R40/KNRK/4-9.12.77. No cross-reaction was? observed with uninfected RD-cells with both the $\frac{\bar{\sigma}}{\mathrm{c}}$ anti-RD-114 and control serum. To absorb a weak cross-reaction of anti-SSAV serum with human cells $\cong$ (NC-37 human lymphoblastoid cell line) the serais were treated with a mixture of human and sheep red $\vec{O}$ blood cells. The rabbit sera were used at $1 / 40-\overrightarrow{-}$ dilution in attempts to detect retrovirus antigens on $\vec{\rho}$ synovial fluid (SFL) and peripheral blood lymphocytes (PBL). Anti-rabbit Ig FITC was purchased from Wellcome Reagents Ltd. and used at $1 / 16_{\infty}^{\omega}$ dilution.

Immunofluorescence with sections of synovial membranes. Material for immunofluorescence was snap-frozen and cut in a cryostat at $-20^{\circ} \mathrm{C}$. Sections ${ }^{-}$ were fixed in acetone for $10 \mathrm{~min}$ and used in indirect $\vec{\square}$ immunofluorescence test as described by Lennette $\Phi$ et al. (1967) and Schmidt et al. (1966). The viral antisera were used at $1 / 40$ dilution in $20 \%$ beef brain음 after absorption with human red blood cells and $\stackrel{\mathbb{}}{-}$ human liver powder. Anti-human IgG, anti-hum IgM, and anti-human C3 were purchased frọ Dakopatts A/S Ltd. and used in an indirect immun fluorescence test at a dilution of $1 / 100$.

Unlabelled antibody-enzyme peroxidase antiperoxidase $(P A P)$ staining. This was done on paraffing sections of synovial membranes as described by Burns (1975). All reagents necessary were purchased $\stackrel{2}{\overrightarrow{7}}$ from Dakopatts A/S Ltd. All dilutions and washings윽 were done in phosphate buffer saline $(\mathrm{pH} \mathrm{7 \cdot 2)}$ supplemented with $2 \%$ normal swine serum.

Radioimmunoassay for detection of viral antigens. $2 \times 10^{5}$ pelleted lymphocytes were mixed with $\frac{0}{2}$ $50 \mu l$ of dilution of antisera/tube and resuspended. The antiserum-lymphocyte mixture was incubated 3 for 2 hours at $4^{\circ} \mathrm{C}$. The cells were washed 3 times $\delta$ with PBS, pH $7 \cdot 2$, containing $2 \%$ FCS, and spun at 2000 r.p.m., 3 times, $5 \mathrm{~min}$. $50 \mu 1$ of ${ }^{125}$ I-labelled goato IgG anti-rabbit Ig containing 60000 counts/100 s (Hart and Marmion, 1977) was added for 2 hours ato $4^{\circ} \mathrm{C}$. The cells were washed 3 times and directly counted in a gamma counter. Three tubes were used. for each dilution and the standard deviation was 0 calculated. Binding ratio was determined as a ratio N of counts obtained with antiviral serum divided byg counts remaining on cells with anti-cell serum.

Radioimmunoassay for detection of retrovirus antibodies. The solid-phase radioimmunoassay for $\stackrel{\oplus}{+}$ antigen detection (Forghani et al., 1974; Hart and 0 Marmion, 1977) was adopted for detection of antibody by extending the times of incubation to 16 hours at $4^{\circ} \mathrm{C}$ for the first antibody reaction and 
4 hours at room temperature for the ${ }^{125}$ I-labelled antibody reaction. The glass vials were seeded with RD-114 RD, RD, KW23 and KNRK at the concentration of 40000 cells/vial. The comparison of control positive sera and the human sera from various groups was made after subtracting the counts bound to uninfected cells from the counts bound to the infected cells and not by calculating the binding ratios.

Complement-mediated cell cytotoxicity. The test used was that described by Detrick-Hooks et al. (1975). In brief, $0.1 \mathrm{ml}$ of $1.5 \times 10^{5} / \mathrm{ml}$ of lymphocyte suspension was mixed with $0.1 \mathrm{ml}$ of antiserum at appropriate dilution for 2 hours at $37^{\circ} \mathrm{C}$. The cells were pelleted and $0.1 \mathrm{ml}$ of rabbit normal serum at $1 / 4-1 / 6$ dilution was added as a source of complement. After 2 hours at $37^{\circ} \mathrm{C}$ the dead cells were detected with trypan blue stain. The percentage of cytotoxic killing was determined by placing the cell suspension in a counting chamber in a phase contrast microscope. A specific virus cytotoxic index was calculated.

$$
\begin{aligned}
\text { Index }= & \text { (the \% of dead cells in rabbit antiviral } \\
& \text { serum in presence of complement }-\% \text { of } \\
& \text { dead cells in absence of complement })
\end{aligned}
$$

$(\%$ of dead cells in rabbit anticell serum in presence of complement $-\%$ of dead cells in absence of complement)

Elution of antibodies. For low $\mathrm{pH}$ elution the method of McCormick et al. (1971) was used. The small pieces of synovial membrane specimens were washed 10 times in PBS. The last wash was checked for absorbance at $280 \mathrm{~nm}$, and, if negative, $10 \mathrm{ml}$ of glycine buffer $(0.15 \mathrm{M}, \mathrm{pH} 2.5)$ were added per gram of wet tissue and the mixture stirred at $4^{\circ} \mathrm{C}$ for 2 hours. The synovial membrane acid eluate was centrifuged immediately at $100000 \mathrm{~g}$ for 1 hour to remove any dissociated 'antigen'. The $\mathrm{pH}$ was readjusted to 7.2 with $0.2 \mathrm{M}$ sodium hydroxide, and the eluate was dialysed for 72 hours against PBS (pH 7.2). The eluates were concentrated to $1 / 10$ th of the original volume by freeze-drying or dialysis against polyethylene glycol $20 \mathrm{M}$.

\section{Results}

RETROVIRUS ANTIGEN ON LYMPHOCYTE MEMBRANES

\section{Membrane immunofluorescence}

In preliminary experiments patients with rheumatoid arthritis $(n=15)$, psoriatic arthropathy $(n=2)$ or osteoarthroses $(n=5)$ were examined. In 12 of these patients only synovial fluid lymphocytes were available; in 10 patients both synovial fluid and peripheral blood lymphocytes were collected. None of the lymphocytes showed membrane immunofluorescence with normal goat serum or antisera to the Moloney leukaemia virus, Mason-Pfizer virus (p12 and p17), feline leukaemia virus (p12 and p27), or Mycoplasma fermentans made in a goat and used as control for cross-species reactions developing during immunisation. However, some batches of lymphocytes, particularly RA synovial lymphocytes, reacted with the antisera to RD-114 and SSAV. The staining took the form either of a finely granular deposit around the periphery of the cell or larger intensely staining clumps at one pole of the cell, suggesting 'capping'. This was observed with 13 out of 15 RA synovial lymphocytes treated with the RD-114 antiserum and 10 out of 15 reacted with the SSAV antiserum. Anti-RD-114 serum, which gave the most intense effect, stained not only most rheumatoid synovial fluid lymphocytes but also lymphocytes from patients with other conditions and from healthy individuals. In general, antigen positive lymphocytes were found consistently, but not invariably, to be present in larger numbers in RA synovial fluids when compared with peripheral blood. The contrast was as much as $80 \%$ of positive lymphocytes in synovial fluid compared with $2 \%$ in the peripheral blood of the same patient.

Various experiments were then undertaken to establish the viral specificity of the reactions. Examination of the viral antisera in gel diffusion tests revealed antibody to calf serum but no reaction with human serum. Consequently, many lymphocyte cultures were done in human serum to avoid possible reactions with absorbed calf serum proteins. The membrane staining persisted. Low titre rheumatoid factor was detected in the goat antisera by agglutination of coated SRBC with human IgG. This was removed by absorption with human serum-coated, glutaldehyde-fixed sheep erythrocytes. This also did not alter the pattern of membrane staining; attempts to block membrane Ig by treatment with anti-human Ig serum before exposure to the viral antiserum were also ineffective.

Inquiry directed to the National Cancer Institute then revealed that the antiviral sera (anti-RD-114 and anti-SSAV) that showed a strong positive reaction with human lymphocytes had been produced against viral antigens grown in cells of human origin. Even though purified viral protein fractions had been used to immunise the goats, they might nevertheless have contained human cell surface antigenic markers in addition to the viral antigens. It was noted that the Mason-Pfizer antiserum, which did not react with RA synovial lymphocytes, had also 
been produced against virus grown in a human lymphoblastoid cell line (NC 37). It is however conceivable that this virus matures without incorporating as many cell surface antigenic markers.

The goat anti-RD-114 serum was then absorbed with human and sheep red blood cells 4 times to give a final dilution of the anti-retroviral sera of $1 / 5$. After this absorption sera lost their positive immunofluorescent staining with 2 pairs of rheumatoid synovial fluid and peripheral blood lymphocytes and reacted only faintly with $R D$ cells infected with RD-114 virus. It is possible that the numerous absorptions required to remove the undesirable anti-'human' activity also removed most of the specific antiviral antibody in the goat sera.

Goat anti-baboon C-type (batch 2) also crossreacted with human antigens, and 4 absorptions with human red blood cells were needed to remove the undesirable specificity, while anti-baboon type-C p28 $\frac{\bar{s}}{\vec{D}}$ appeared free of cross-reactivity measured by $\triangle$ agglutination of HRBC. The baboon antisera free of $ळ$ 'normal human antigen' cross-reactivity, failed to stain 2 pairs of rheumatoid synovial and peripheral blood lymphocytes.

Table 1 Distribution of membrane immunofluorescence with rabbit antiretroviral sera to $R D-114(R 35 / R D-114$ $\left.R K_{13} / 6\right)$ and to $S S A V$ viruses $(R 42 / K W 23 / 4)$ at the dilution 1/40. In this study controls included sera produced against uninfected cells $\left(R 33 / R K_{13} / 6\right.$ and $\left.R 40 / K W R K / 4\right)$. No specific binding was observed with rheumatoid or other lymphocytes irrespective of trypsin treatment

\begin{tabular}{|c|c|c|c|c|c|c|c|}
\hline \multirow[t]{2}{*}{ No. } & \multirow[t]{2}{*}{ Diagnosis } & \multirow[t]{2}{*}{ Lymphocytes } & \multicolumn{5}{|c|}{ Retrovirus and control antisera } \\
\hline & & & $\begin{array}{l}R 35 / R D-114 R K_{13} / 6 \\
-29.8 .77\end{array}$ & $\begin{array}{l}R 33 / R K_{13} / 6 \\
-29.8 .77\end{array}$ & $\begin{array}{l}R 42 / D W 23 / 4 \\
-9.12 .77\end{array}$ & $\begin{array}{l}R 40 / K N R K / 4 \\
-9.12 .77\end{array}$ & ఠ \\
\hline \multirow[t]{2}{*}{770071} & RA & SFL & - & - & $\cdots$ & .. & $\frac{10}{3}$ \\
\hline & (14 years) & PBL & - & - & . & . & ত্ণ \\
\hline \multirow[t]{2}{*}{770098} & & SFL & - & - & $\cdots$ & . & D \\
\hline & (24 years) & $\begin{array}{l}\text { SFLTRL } \\
\text { PBL }\end{array}$ & $\bar{z}$ & $\overline{-}$ & $\cdots$ & $\cdots$ & $\Omega \vec{c}$ \\
\hline \multirow[t]{4}{*}{770102} & Seroneg RA & SFL & - & - & $\ddot{.}$ & $\ddot{.}$ & 음 \\
\hline & (2 years) & SFTRL & -- & - & . & .. & $\leqq$ \\
\hline & & PBL & - & - & $\cdots$ & .. & \\
\hline & & PBLTRL & -- & - & . & .. & $\stackrel{+}{+}$ \\
\hline 770099 & $\begin{array}{l}\text { RA } \\
\text { (13 years) }\end{array}$ & SMTWL & - & - & . & $\cdots$ & 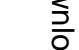 \\
\hline 770100 & $\begin{array}{l}\text { RA } \\
\text { (7 years) }\end{array}$ & SMTRL & - & - & $\cdots$ & . & $\stackrel{2}{\frac{2}{D}}$ \\
\hline \multirow[t]{2}{*}{770108} & RA & SFL & - & - & . & $\cdot$ & อ \\
\hline & (9 years) & $\begin{array}{l}\text { SFTRL } \\
\text { PBL }\end{array}$ & $\overline{-}$ & $\overline{-}$ & $\begin{array}{l}. . \\
. .\end{array}$ & $\ddot{.}$ & $\overrightarrow{\bar{O}}$ \\
\hline \multirow[t]{3}{*}{770109} & RA & SFL & - & - & 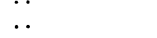 & $\ddot{x}$ & 3 \\
\hline & (20 years) & SFTRL & - & - & .. & .. & $\underset{\rightleftharpoons}{\beth}$ \\
\hline & & PBL & - & - & $\because$ & $\because$ & 官 \\
\hline \multirow{2}{*}{770144} & RA & SFL & - & - & \pm & \pm & \\
\hline & (8 years) & $\begin{array}{l}\text { SFTRL } \\
\text { PBL }\end{array}$ & - & - & $\ddot{ \pm}$ & $\ddot{t}$ & ஹ్ \\
\hline \multirow[t]{3}{*}{770148} & RA & SFL & - & - & \pm & \pm & \\
\hline & (20 years) & SFTRL & - & - & \pm & \pm & \\
\hline & & PBL & - & - & .. & .. & \\
\hline \multirow[t]{2}{*}{770149} & RA & SFL & - & - & . & .. & ชి \\
\hline & (24 years) & $\begin{array}{l}\text { SFTRL } \\
\text { PBL }\end{array}$ & $\overline{-}$ & $\overline{-}$ & $\ddot{.}$ & $\because$ & 3 \\
\hline \multirow[t]{2}{*}{770122} & RA & SFL & . & .. & $\ddot{-}$ & $\ddot{-}$ & 으 \\
\hline & (15 years) & PBL & .. & .. & - & - & \\
\hline \multirow[t]{2}{*}{770123} & RA & SFL & .. & .. & - & - & $D$ \\
\hline & (6 years) & PBL & .. & .. & - & - & \\
\hline \multirow[t]{2}{*}{770164} & Yearly RA & SFL & .. & .. & \pm & \pm & \\
\hline & (1 year) & PBL & .. & . & \pm & \pm & o \\
\hline \multirow[t]{3}{*}{770004} & $\begin{array}{l}\text { RA } \\
\text { (15 years) }\end{array}$ & $\begin{array}{l}\text { SFL } \\
\text { PBL }\end{array}$ & $\cdots$ & $\cdots$ & \pm & \pm & \\
\hline & $\begin{array}{l}\text { (15 years) } \\
\text { Healthy }\end{array}$ & $\begin{array}{l}\text { PBL } \\
\text { I PBL }\end{array}$ & $\begin{array}{l}. . \\
. .\end{array}$ & $\begin{array}{l}. . \\
. .\end{array}$ & $\begin{array}{l} \pm \\
\pm\end{array}$ & $\begin{array}{l} \pm \\
\pm\end{array}$ & O \\
\hline & & II PBL & . & . & \pm & \pm & $\tilde{\omega}$ \\
\hline \multirow{2}{*}{\multicolumn{3}{|c|}{$\begin{array}{l}\text { NC-37 Human lymphoid cell-line } \\
\text { SSAV infected NC-37 }\end{array}$}} & . & $\cdots$ & \pm & \pm & ס \\
\hline & & & $\ddot{i}+$ & $\ddot{-}$ & +++ & \pm & \\
\hline \multirow{2}{*}{\multicolumn{3}{|c|}{$\begin{array}{l}\text { RD-114 infected RD cells } \\
\text { RD cells } \\
\text { KW }\end{array}$}} & \pm++ & $\overline{-}$ & $\cdots$ & $\cdots$ & \\
\hline & & & $=$ & - & $\ddot{+}+*$ & $\ddot{*}$ & $\bar{D}$ \\
\hline \multicolumn{3}{|c|}{$\begin{array}{l}\text { KW23 } \\
\text { KNRK }\end{array}$} & - & - & $-*$ & \pm & \\
\hline
\end{tabular}

,,,$++++++ \pm=$ Various degrees of immunofluorescence. $-=$ Negative immunofluorescence. $\ldots=$ Not tested. SFL $=$ Cultured synovial $\bar{O}$ fluid lymphocytes. SFLTR =Trypsinised and cultured synovial fluid lymphocytes. $S M L=S y n o v i a l$ membrane lymphocytes. PBL $=$ Peripheral blood lymphocytes. *The immunofluorescence was obtained only after numerous absorptions with rat liver powder and KNRK cells and thus $\Omega$ differed from the single absorption with HRBC and SRBC used for the other tests. 
In further attempts to elucidate the difference in the immunofluorescence patterns observed with rheumatoid synovial fluid (SFL) and peripheral blood lymphocytes (PBL) new antisera were raised in rabbits. The RD-114 virus was adapted to growth in rabbit kidney (RK13) cells grown in rabbit serum. The SSAV was grown in KNR cells, cultured in rabbit serum. The partly purified virus from these cultures was then used as an inoculum for the rabbits. Similar fractions from uninfected cells were inoculated into rabbits to provide control sera. Table 1 shows the results of testing synovial and peripheral blood lymphocytes with these antisera. All lymphocytes were negative with anti-RD-114 serum and its control serum. Anti-SSAV serum and control serum stained $1-2 \%$ of cells, but the majority were negative. Satisfactory staining was obtained with RD-114 infected control cells.

The study was extended by trypsinising the lymphocytes, in particular those from the synovial fluid, before immunofluorescent staining. Trypsin treatment is reported to remove immune complexes that block the receptors for sheep erythrocytes on T-lymphocytes from RA patients (Wangel and Klockars, 1977); such complexes might conceivably mask retrovirus antigen. Nevertheless, all immunofluorescent tests were negative with specific antiviral sera, including 2 samples of lymphocytes isolated from rheumatoid synovial membranes rather than harvested from SF.

The negative results by immunofluorescence were checked by radioimmunoassay and complement mediated cell cytotoxicity as alternative methods of detecting cell antigens.

\section{Radioimmunoassay}

Nine samples of trypsinised cells from synovial fluid and 12 cultured sets of lymphocytes all with matched peripheral blood lymphocytes were tested by radioimmunoassay for the binding of antibodies to RD-114 and SSAV. In control experiments RD-114 infected cells showed substantially higher binding ratios with antiviral sera (calculated as 2.75 at serum dilution $1 / 100 ; 2.89$ at serum dilution of $1 / 300$ ) than with sera inoculated with cells alone (R33/ RK13/ 6-29.8.77 and R40/KNRK/4-9.12.77) (Figure 1). The trypsinised and untreated synovial fluid lymphocytes, and peripheral blood lymphocytes with the exception of one batch of peripheral blood lymphocytes from patient 770152 , did not show binding ratios at the dilutions of $1 / 100-1 / 300$ in excess of those observed with uninfected RD cells or normal peripheral blood lymphocytes (Table 2).

Complement-mediated cell cytotoxicity

After the completion of the tests on lymphocytes by

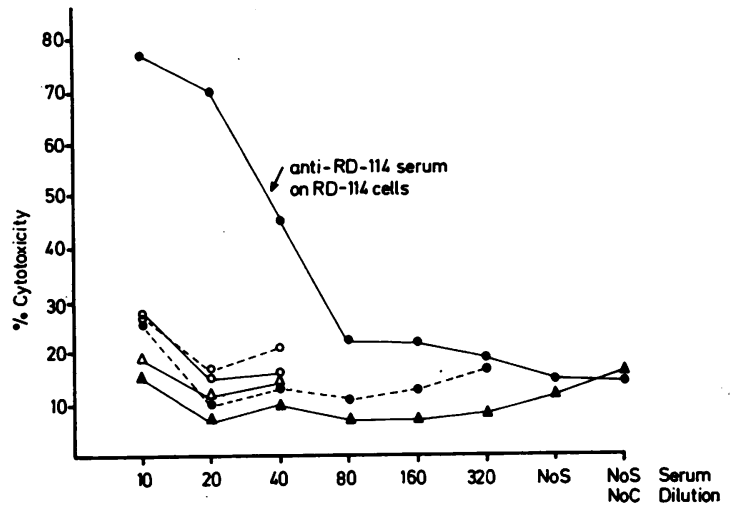

Fig. 1 Cytotoxicity by anti-RD-114 serum (-R35/ $\left.R D-114 R K_{13} / 6-9.8\right)$ and anti-cell control serum $\left(-R 33 / R K_{13} / 6-29.8\right)$ on $R D-114$ infected $(0)$ and control $R D$ cells $(\Delta)$ in the presence $(O ; \Delta)$ and absence of complement $(O \Delta)$. NoS-no serum. NoC-no complement.

immunofluorescence and radioimmunoassay Oliver and Pillai (1977) reported that retrovirus antigens on the surface of leukaemic cells could be detected by complement-mediated cell cytotoxicity. In particular, goat anti-SSAV serum reacted with lymphocytes from patients with acute lymphocytic leukaemia. It was conceivable that this technique might, for reasons of sensitivity or different mechanisms, reveal antigens that the other 2 techniques had not detected.

In applications of the method in the present investigation cell viability was detected by a dyeexclusion method. The cytotoxic activity of the antiserum to RD-114 was determined by titration on infected and uninfected RD cells with and without rabbit complement. The 'anticell' serum (R33 RK13/6-28.8.77) was included as a further control. The results are shown in Fig. 1; there was a clear cut difference between specific antigen and controls. It will be noted that the $50 \%$ cytotocixity was produced by a dilution of $1 / 40$ of the RD-114 antiserum-this contrasts with a titre of at least $1 / 3000$ obtained by radioimmunoassay (Fig. 2). As a result of these titrations a dilution of $1 / 20$ of the RD-114 antiserum was chosen for cytotoxicity tests with synovial (SFL) and peripheral blood lymphocytes (PBL) from 6 RA patients together with PBL from 3 healthy persons. Four batches of RA-SFL were treated with trypsin before testing (SFLTR). Three other pairs of RA-SFL and PBL plus 3 lots of PBL from healthy persons were tested with a $1 / 20$ dilution of anti-SSAV serum.

The levels of cytotoxicity observed with both of the viral antisera were low with all batches of 
Table 2 Detection of retrovirus antigens by indirect radioimmunoassay on lymphocytes

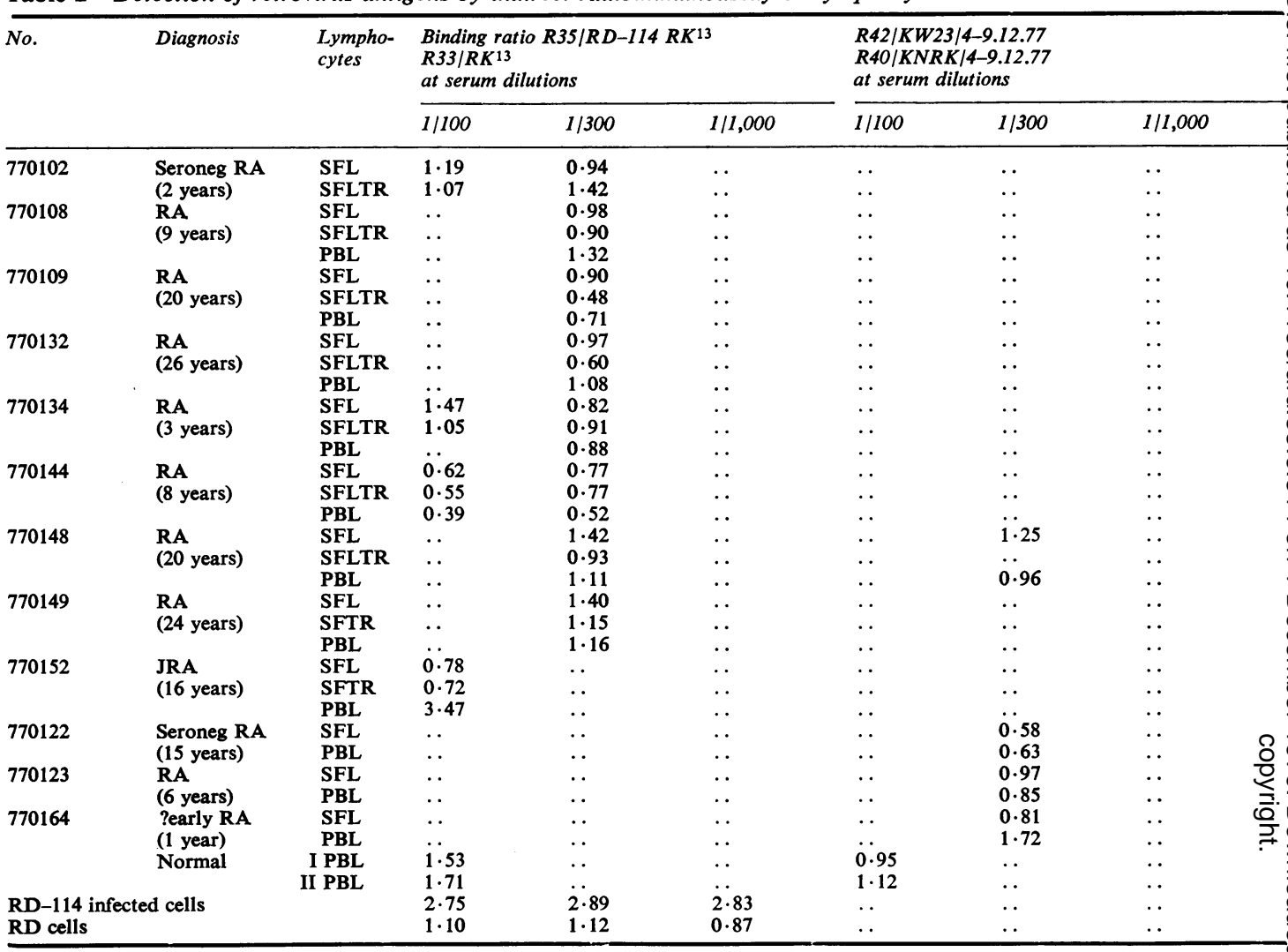

SFL = Synovial fluid lymphocytes. SFLTR = Trypsinised synovial fluid lymphocytes. PBL = Peripheral blood lymphocytes...$=$ Not tested.

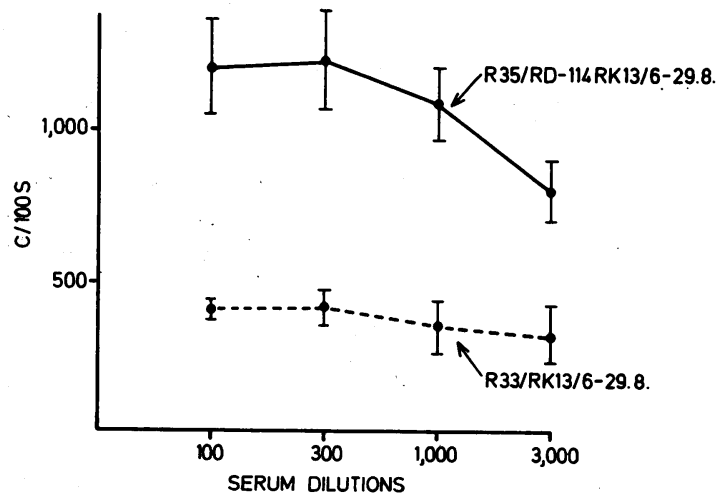

Fig. 2 The differential binding of anti-RD-114 serum $\left(R 35 / R D-114 R K_{13} / 6-29 \cdot 8\right)$ and control anti-'cell' serum $\left(R 35 / R K_{13} / 6-29.8\right)$ to $R D-114$ infected $R D$ cells. Each point represents the mean calculated from 3 observations. The standard deviation is indicated by horizontal line at each serum dilution. lymphocytes and did not reveal any trend unobserved by the other techniques already employed (Fig. 3 ) With the anti-RD-114 serum the mean values for:RA-PBL, SFL and SFLTR were $4.8 \%, 6 \cdot 1 \%$, and $1.8 \%$ respectively, compared, with $62 \%$ for the antiserum on RD-114 infected RD cells, and $0 \%$ of normal PBL and uninfected RD cells. It was notedo that the untreated synovial fluid lymphocytes were more fragile and the background levels of dead cellso were consistently higher than those found in preparations of peripheral blood lymphocytes fromo the same patient. This observation fits with the leakage of cell macromolecules from RA-SL noted in other work (Norval, personal communication).

SEARCH FOR RETROVIRUS ANTIGENS IN SECTIONS OF SYNOVIAL MEMBRANE It was clear from the foregoing work that antigens related to primate, murine, and feline retroviruses. are not present in significant amounts on RA synovia lymphocytes. Other work (see Introduction) has nof 


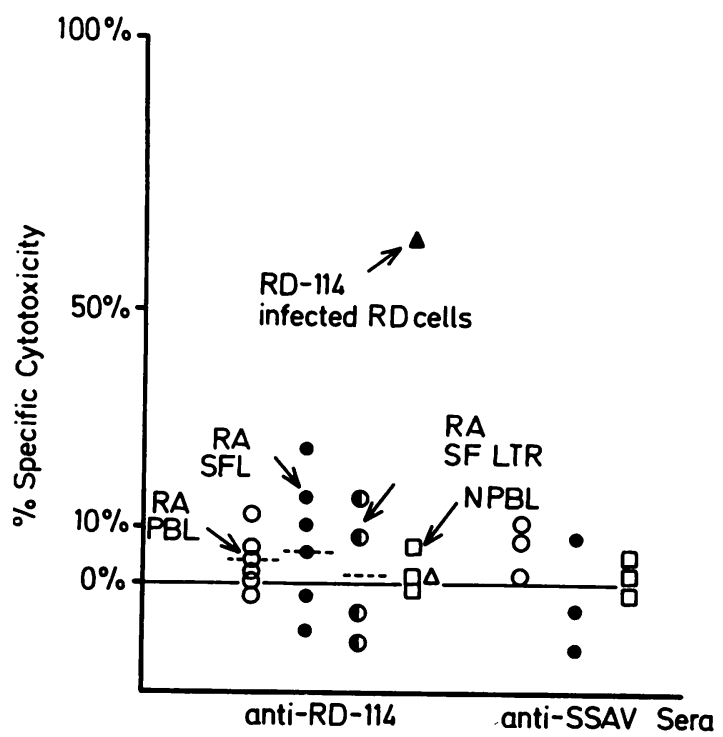

Fig. 3 Examination of retroviral antigen specific complement-mediated cytotoxicity using rheumatoid peripheral blood lymphocytes $(R A P B L-0)$, rheumatoid synovial blood lymphocytes obtained from the same patients on the same day (RA SFL- $\bullet$ ), trypsinised rheumatoid synovial fluid lymphocytes (RA SF LTR-D), normal peripheral blood lymphocytes (NPBL- $\square$ ). Controls included $R D-114$ infected $R D$ cells $(\Lambda)$ and uninfected $R D$ cells $(\Delta)$.

revealed retrovirus reverse transcriptase in RA synovial membrane extracts or synovial fibroblast cultures. It seemed important, nevertheless, to examine sections of synovial membrane that would include cells not represented in suspensions of synovial lymphocytes or fibroblast cultures. (A possible analogy was the claim by Panem et al.
(1976) to have demonstrated retrovirus antigens in the mesangial cells and along the glomerular capillary walls in SLE kidneys.)

Accordingly, fixed frozen sections and dewaxed paraffin sections from 5 RA and 5 non-RA synovial membranes were examined, respectively, by immunofluorescence and immunoperoxidase techniques, with the anti-RD-114 and SSAV sera and their corresponding control 'anticell' antisera, and also with antisera to IgG, IgM and C3 (Table 3). Immunofluorescence or immunoperoxidase staining was not observed with the viral or the control antisera. As would be expected, bound complement and immunoglobulin were detected, particularly in the RA membranes, and particular attention was paid to these areas when looking for viral specific staining. There was less staining by the anti-IgG serum than might have been predicted. 'Masking' IgM RF might have to be removed to increase this, but it was not attempted.

\section{ANTIBODIES REACTIVE WITH PRIMATE \\ ONCORNAVIRUS ANTIGENS}

Absorbed anti-RD-114 rabbit serum was used to determine the optimal conditions and specificity for the solid phase radioimmunoassay with RD-114 infected and control RD cells (Fig. 2). The assay of antibodies to RD-114 and SSAV viruses in RA and SLE patient's sera, and those from other subjects, was attempted by the same solid-phase radioimmunoassay system with infected and uninfected cells.

The half-log dilutions of patient's sera chosen for the study were $1 / 100,1 / 300$, and $1 / 1000$. Fig. 4 shows the counts bound to RD-114 infected RD cells, Fig. 5 shows the counts bound to KW23 (SSAV infected KNRK cells) after the counts bound to uninfected cells had been subtracted. There was no

Table 3 Detection of serum proteins and retrovirus antigens by indirect immunofluorescence (IF) and immunoperoxidase (IP) in, respectively, frozen and paraffin sections of synovial membranes from patients with various diagnoses. Sera used in this study were identical to those previously described (Table 1)

\begin{tabular}{|c|c|c|c|c|c|c|c|c|c|c|}
\hline \multirow[t]{2}{*}{ No. } & & & \multirow[t]{2}{*}{ Diagnosis } & \multicolumn{7}{|c|}{ Antiserum } \\
\hline & & & & $I g G$ & $I g M$ & $C 3$ & $R D-114$ & $C$ & $S S A V$ & $C$ \\
\hline IP & $\begin{array}{l}7 \\
8 \\
9\end{array}$ & $\begin{array}{l}\text { RA } \\
\text { RA } \\
\text { RA } \\
\text { OA }\end{array}$ & $\begin{array}{l}\text { (12 years) } \\
\text { (seronegative } \\
20 \text { years) } \\
\text { ( } 4 \frac{1}{2} \text { years) } \\
\text { (8 years) }\end{array}$ & $\begin{array}{l} \pm \\
++ \\
++ \\
-\end{array}$ & $\begin{array}{l}++ \\
- \\
+\end{array}$ & $\begin{array}{l}+ \\
- \\
+\end{array}$ & $\begin{array}{l}- \\
- \\
-\end{array}$ & $\begin{array}{l}- \\
- \\
-\end{array}$ & $\begin{array}{l}- \\
- \\
-\end{array}$ & $\begin{array}{l}- \\
- \\
-\end{array}$ \\
\hline
\end{tabular}

C3 = anti-complement serum. $\mathbf{C}=$ anticell sera. 
difference in the binding to the infected RD-114 cells and KW23 between the various groups I, II, and III of human sera. Removal of RF did not alter the results. There were, however, substantial differences in the binding of the anti-RD-114 serum (detectable end point of the titration $1 / 3000$ ) and anti-SSAV rabbit serum (end point $1 / 10000$ ) compared with the pattern of binding of all the human sera tested. These results thus do not support the presence of humoral antibodies to retrovirus antigens in normal population at the dilutions tested. Rheumatoid synovial membrane eluates were used to eliminate the possibility of retroviral antibodies bound in the immune complexes, which might not therefore be detectable in the sera of the patients. Eight acid eluates were tested by indirect immunofluorescence on both RD-114 and SSAV infected cells and were found to be negative.

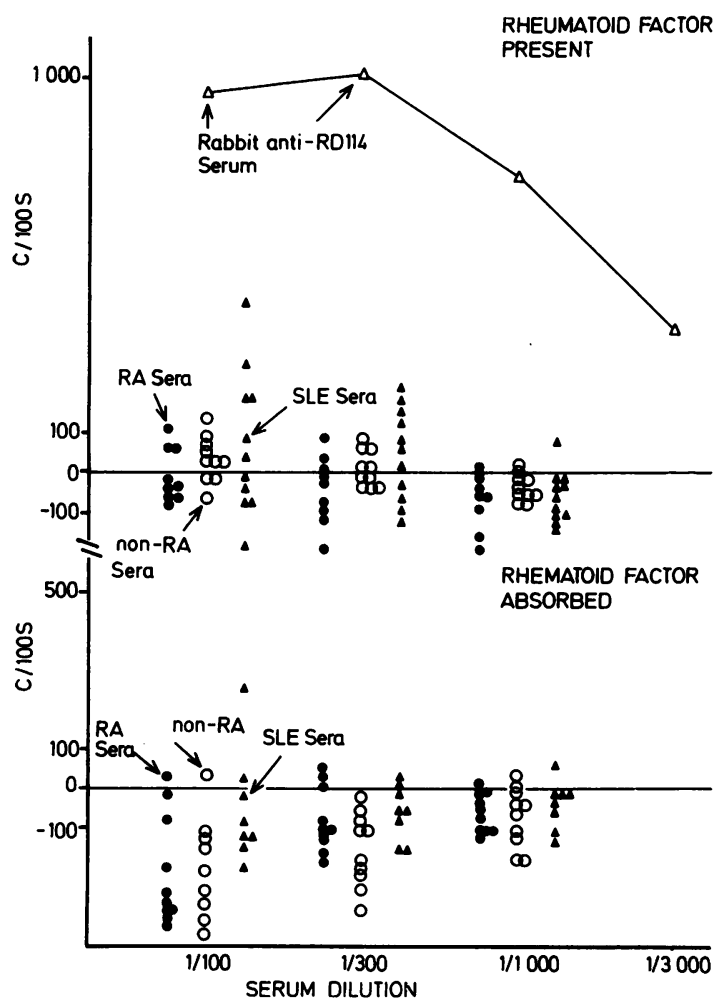

Fig. 4 Amount of Ig in human serum groups $I, I I$, and III bound in a solid phase radioimmunoassay with $R D-114$ virus infected cells after the values for bound globulin to uninfected $R D$ cells were subtracted. Sera were tested before and after absorption with human serum Cohn fraction II. Symbols; -Group I, RA

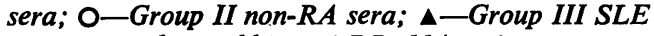
sera; $\triangle$-values rabbit anti-RD-114 antiserum

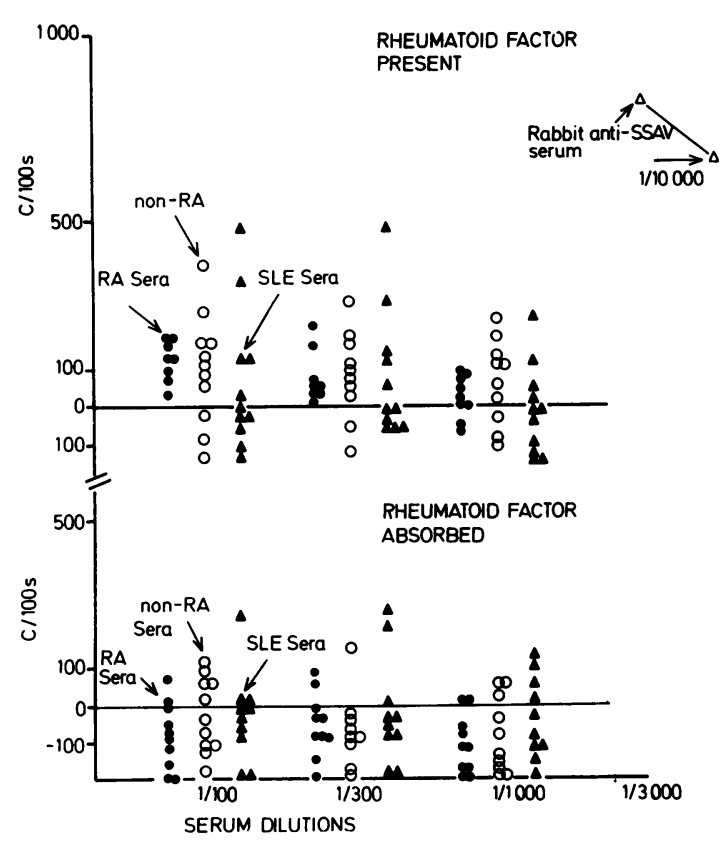

Fig. 5 The amount of Ig in human serum groups I, $I I$, and III, bound in a solid-phase radioimmunoassay to SSAV infected $K N R K$ cells ( $K W 23$ cell line) after subtraction of that bound to uninfected KNRK cells. Sera were tested before and after absorption with human serum Cohn fraction II. Symbols; -Group I, RA sera; O-Group II, non-RA sera; $\Delta-$ Group III, $S L E$ sera; $\triangle$-values for rabbit anti-SSAV antiserum

\section{Discussion}

The interactions between lymphocytes and C-type retroviruses are complex and poorly understood. From a murine model of the immunological activation of endogenous $\mathrm{C}$-type murine retroviruses the activated viruses are predominantly associated with T-lymphocytes in vivo (Hirsch, 1976). Other observations suggest that lymphocytes in certain stages of differentiation may be highly susceptible to activation of endogenous virus (Obata et al., 1975). From studies in vitro on mixed lymphocyte reaction (MLR) the activated viruses detected were observed by electron microscopy to bud exclusively from lymphoblasts (Andre-Schwartz et al., 1973). These observations, together with experimental evidence indicating that lymphocytes, especially SFL, in rheumatoid arthritis behave differently in mitogenic stimulation experiments (Stratton, 1972; Panayi, 1973; Holborow et al., 1975), and show different ability to support the replication of various viruses (Denman et al., 1976) made it reasonable to investi- 
gate possible virus infection of these cells. In an accompanying paper (Norval et al., 1979) we describe experiments which failed to detect productive infection of rheumatoid synovial lymphocytes. The 'human xenotrophic' virus was not also activated by immunological stimulation (MLR) or detected in fusion with cell lines proved to be permissive for primate retroviruses.

The serological study of rheumatoid synovial and peripheral blood lymphocytes reported here was initiated with knowledge of the cross-reactivity of the known human retrovirus isolated with the SSAV/ gibbon ape primate group of infectious virus and the endogenous group of RD-113/baboon (Teich et al., 1975; Okabe et al., 1976). Initial results of the study using goat sera supplied by NCI, Bethesda, were encouraging. The immunofluorescence with antiSSAV (TE) and anti-RD-114 (TE) goat sera gave a series of positive results with rheumatoid synovial lymphocytes, while other goat sera were negative (anti-murine leukaemia virus, anti-feline leukaemia viral proteins p12 and p27, and anti-Mason Pfizer mammary tumour virus proteins $\mathrm{p} 12$ and 27). Superficially this fitted the pattern of cross-reactivity observed with recently isolated human retrovirus. However, further experiments revealed that these sera also stained normal human lymphocytes at lower intensities, agglutinated human red blood cells and cross-reacted with human IgG coated sheep blood cells (data not shown), thus indicating that the main part of the immunofluorescence observed was due to the cross-raection with 'normal' human antigens.

To overcome the problems of the cross-reactivity RD-114 virus for immunisation was grown in a homologous system; that is, rabbits were immunised with the virus grown in rabbit cells and normal rabbit serum. This method was used in preparing the rabbit anti-RD-114 and the reagent specific for viral antigens was used as in the immunofluorescent study, radioimmunoassay and complement-dependent cytotoxicity to provide the answer whether partially expressed $\mathrm{C}$-type virus antigens on the rheumatoid synovial lymphocytes could be underlying the 'disordered immunoregulation' suggested in rheumatoid patients. All tests employed were negative with specific rabbit sera, except 1 case of juvenile rheumatoid arthritis, whose peripheral blood lymphocytes showed the presence of retrovirus antigens on the cell surface measured by radioimmunoassay, but the synovial fluid lymphocytes from the same source were negative. Work is now in progress to repeat the observation and to attempt an isolation of human retrovirus from this patient's peripheral blood lymphocytes.

Anti-SSAV serum produced in rabbits showed no specific viral antigens on the surface of rheumatoid synovial or peripheral blood lymphocytes. This antiserum was not produced by the homologous system as the attempts to grow SSAV virus in RK13 were not successful (data not shown). But unlike the goat sera from NCI the cells for the growth of immunising antigens were at least of a different species (rat kidney) to the eventual test cell. The antiserum cross-reacted strongly with rat cells, and the low level of cross-reactivity with normal human antigens was removed by absorption. The rabbit sera were specific for the viral antigens, that is, the anti-RD-114, serum did not stain SSAV infected cells, in accordance with observations elsewhere (Panem et al., 1977).

An extension of this work pertinent to rheumatoid lymphocytes was also carried out by trypsinising the cells prior to the immunological tests. The work of Wangel and Klockars (1977) showed that immune complexes blocked SRBC receptors on rheumatoid T-lymphocytes, and these were removed by trypsinisation. The SRBC receptors were allowed to regenerate by culturing the lymphocytes overnight in the absence of immune complexes. The same method of trypsinisation and regeneration of 'presumptive' viral antigens on lymphocyte cell membranes was followed. This did not, however, yield any positive results with specific viral antisera. The lymphocyte preparations also included cells from enzymedigested synovial membranes. In this communication we also include a small antibody survey in an attempt to elucidate a possible involvement of retroviruses in the rheumatoid arthritis. The method used for the detection of antibodies reactive with primate retrovirus antigens is different from those published in this field.

Solid-phase radioimmunoassay (RIA) directly using infected cells has several advantages: (i) there is no need for lengthy purification of the viral antigens; (ii) all viral antigens are present in the acetone fixed infected cells (core antigens, reverse transcriptase will be present prior to the assembly into the infectious virions; (iii) an additional control can be set up for all dilutions of human sera, the counts bound to the uninfected cells can be subtracted from counts bound to the virally infected cells, thus binding to cellular antigens and fetal calf serum absorbed from tissue cultures will be excluded in each sample.

Although it is not possible to compare the sensitivity to that of previous work, it seems that it might be of a similar order. Positive rabbit sera anti-SSAV and anti-RD-114 titrated to titres of 10000 and 3000 respectively. The range of antibody titres in autogenous immune response to endogenous virus in mice is $\mathbf{0 - 5 1 2 0}$ by radioimmunoprecipitation 
(RIP) (Ihle and Hanna, 1977) and 0-320 in normal human sera (Snyder et al., 1976).

Human sera dilutions of $100,300,1000$ were chosen on the assumption that if retroviruses were involved in 'autoimmune' diseases one should see a substantial difference in binding to infected cells compared to uninfected at these dilutions. Human sera were absorbed to remove Forsmann antigen crossreactivity, thus making the set of controls complete. There was no difference in binding in the assay used between the 3 groups of subjects tested, including RA, SLE and non-RA controls. Modest amounts of antibodies bound to SSAV antigens appeared to be removed with absorption of RF. The possibility that the retroviral antibody was removed by binding in immune complexes and lodged in the rheumatoid synovial membranes was excluded by the studies of acid eluates and further by the direct investigation the sections of membranes. The negative results would suggest the absence of antibodies in the serum reflects the absence of retrovirus expression and not their binding in immune complexes, a mechanism suggested in the murine model of AKR mice (Batzing et al., 1974).

We conclude that persistent infection or partial expression of retroviruses cross-reactive with RD-114 and SSAV antigens is not the stimulus in the chronic inflammation of rheumatoid arthritis and that retrovirus antigens expressed on RA lymphocytes are not responsible for their apparent refractiveness to mitogen stimulation or viral superinfection.

This work was supported by a grant from the Nuffield Foundation. We wish to acknowledge the help of Mrs Leonora Hislop; the consultant surgeons at the Princess Margaret Rose Hospital, Edinbugh, for providing the synovial membrane specimens; and the consultants at the Northern General Hospital for the synovial fluid specimens.

\section{References}

Abrahamsen, T. G., Fröland, S. S., Natvig, J. B., and Pahle, J. (1975). Elution and characterization of lymphocytes from rheumatoid inflammatory tissue. Scandinavian Journal of Immunology, 4, 823-830.

Andre-Schwartz, J., Schwartz, R. S., Hirsch, M. S., Phillips, M. S., and Black, P. H. (1973). Activation of leukaemia virsuses by graft-versus-host and mixed lymphocyte culture reaction: electron microscopic evidence of C-type particles. Journal of the National Cancer Institute, 51, 507-518.

Aoki, T., Walling, M. J., Bushar, G. S., Liu, M., and Hsu, K. C. (1976). Natural antibodies in sera from healthy humans to antigens on surfaces of type-C RNA viruses and cell from primates. Proceedings of the National Academy of Sciences of the USA, 73, 2491-2495.

Avrameas, S., Taudou, B., and Chuilon, S. (1969). Glutaldehyde, cyanuric chloride and tetrazotized O-dianisidine as coupling reagents in passive haemagglutination test. Immunochemistry, 6, 67-76.
Batzing, B. L., Yurconic, M., Jr., an Hanna, M. G. (1974)d. Autogenous immunity to endogenous RNA tumour virus: chronic humoral immune response to virus envelope antigens in $\mathrm{B} 6 \mathrm{C} 3 \mathrm{Fl}$ mice. Journal of the National Cancer Institute, 52, 117-131.

Burns, J. (1975). Immunoperoxidase localisation of hepatitis $B$ antigen (HB) in formalin-paraffin processed liver tissue. Histochemistry, 44, 133-135.

Charman, H. P., Kim, N., White, M., Marquardt, H., Gilden, R. V., and Kawakami, T. (1975). Natural and experimentally induced antibodies to defined mammalian type-C virus proteins in primates. Journal of the National Cancer Institute, 55, 1419-1424.

Denman, A. M. (1975). The viral theory of connective tissue diseases: a review. Medical Biology, 53, 61-84.

Denman, A. M., Pelton, B. K., Appleford, D., and Kinsley, M. (1976). Virus infections of lympho-reticular cells and autoimmune diseases. Transplantation Reviews, 31, 79-115.

Detrick-Hooks, B., Borsos, T., and Rapp, H. J. (1975). Quantitative comparison of techniques used to measure complement-mediated cytotoxicity of nucleated cells. Journal of Immunology, 114, 287-290.

Forghani, B., Schmidt, M. J., and Lennette, B. H. (1974) Solid phase radioimmunoassay for identification of Herpes virus hominis types 1 and 2 clinical material. Applied Microbiology, 28, 661-667.

Gallagher, R. E., and Gallo, R. C. (1975). Type-C RNA tumour virus isolated from cultured human acute myelogenous leukemia cells. Science, 187, 350-353.

Harris, R. (1970). Tissue typing using a routine one step lymphocyte separation procedure. Journal of Haematology 18, 228-231.

Hart, H., and Marmion, B. P. (1977). Rubella virus an rheumatoid arthritis. Annals of the Rheumatic Diseases, 36 3-12.

Hirsch, M. S. (1976). Immune activation of endogenous viruses. Tumour Virus Infections and Immunity, p. 175. Edited by R. L. Crowell, H. Friedman, and J. E. Prier. University Park Press: Baltimore, London and Tokyo.

Holborow, E. J., Sheldon, P. J., and Papamichael, M. (1975). Studies on synovial fluid lymphocytes in rheumatoid arthritis. Rheumatology, 6, 215-218.

Ihle, J. N., and Hanna, M. G. (1977). Natural immunity to endogenous oncornaviruses in mice. Contemporary Topics in Immunobiology, 6, 169-174.

Imamura, M., Phillips, P. E., and Mellors, R. C. (1976). The occurrence and frequency of type- $\mathrm{C}$ virus like particles in placentas from patients with SLE and form normal subjects. American Journal of Pathology, 83, 383-394.

Kurth, R., Teich, N. M., Weiss, R., and Oliver, R. T. D. (1977). Natural human antibodies reactive with primate type-C viral antigens. Proceedings of the National Academy of Sciences of the USA, 74, 1237-1241.

Lennette, E. H., Woodie, J. D., and Schmidt, N. J. (1967). A modified indirect immunofluorescent staining technique for the demonstration of rubella antibodies in human sera. Journal of Laboratory and Clinical Medicine, 69, 689-698.

Marmion, B. P. (1978). Infection, autoimmunity and rheumatoid arthritis. Clinics of Rheumatic Diseases, 4, 565-586.

McAllister, R. M., Nelson-Rees, W. A., Johnson, E. Y., Rongey, R. W., and Gardner, W. B. (1971). Disseminated rhabdosarcoma formed in kittens by cultured human rhabdosarcoma cells. Journal of the National Cancer Institute, 47, 603-611.

McAllister, R. M., Nicolson, M., Gardner, M. B., Rongey, R. W., Rasheed, S., Sarma, P. S., Huebner, R. J., Hatanaka, M., Orozslan, S., Gilden, R. V., Kabigting, A., and Vernon, L. (1972). C-type virus released from cultured human rhabdosarcoma cells. Nature New Biology, 235, 3-6 
McCormick, J. N., Faulk, W. P., Fox, H., and Fudenberg, H. H. (1971). Immunohistological and elution studies of the human placenta. Journal of Experimental Medicine, 133, 1-18.

Mellors, R. C., and Mellors, J. W. (1975). Antigen related to mammalian type-C RNA viral p30 protein is located in renal glomeruli in human systemic lupus erythematosus. Proceedings of the National Acade of my Sciences of the USA, 73, 233-237.

Metzgar, R. S., Mohanakumar, T., and Bolognesi, D. P. (1976). Relationships between membrane antigens of human leukemic cells and oncogenic RNA virus structural components. Journal of Experimental Medicine, 143, 47-63.

Norval, M., Ogilvie, M. M., and Marmion, B. P. (1975). DNA polymerase activity in rheumatoid synovial membranes. Annals of the Rheumatic Diseases, 34, 205-212.

Norval, M., and Marmion, B. P. (1976). Attempts to identify viruses in rheumatoid synovial cells. Annals of the Rheumatic Diseases, 35, 106-113.

Norval, M., Hart, H., and Marmion, B. P. (1979). Viruses and lymphocytes in rheumatic diseases. I. Studies on cultured rheumatoid lymphocytes. Annals of the Rheumatic Diseases, 38, 507-513.

Obata, Y., Ikeda, H., Stockert, E., and Boyse, E. A. (1975). Relation of $\mathrm{G}_{\mathrm{Ix}}$ antigen of thymocytes to envelope glycoprotein of murine leukaemia virus. Journal of Experimental Medicine, 141, 188-197.

Okabe, H., Gilden, R. V., Hatanaka, M., Stephenson, J. R. Gallagher, R. E., Gallo, R. C., Tronick, S. R., and Aaronson, S. A. (1976). Immunological and biochemical characterisation of type-C viruses isolated from human acute myelogenous leukaemia cells. Nature, 260, 264-266.

Oliver, T. D., and Pillai, A. (1977). Reactivity of antisera to oncornavirus proteins with human leukaemia cells. Proceedings of the Royal Society of Medicine, 70, 556-559.

Panayi, G. S. (1973). Response of rheumatoid synovial fluid lymphocytes to non-specific mitogens. Lancet, 2, 512-513.

Panem, S., Nelson, G., Ordonez, M. D., Kirstein, W. H. Katz, A. I., and Spargo, B. H. (1976). C-type virus expression in systemic lupus erythematosus. New England Journal of Medicine, 295, 470-475.

Panem, S., Prochownik, E. V., Knosh, W. M., and Kirstein, W. H. (1977). Cell generation and type-C virus expression in the human embryonic cell strain HEL-12. Journal of General Virology, 35, 487-495.

Phillips, P. E., and Hargrave-Granda, R. (1978). Type C oncornavirus isolation studies in systemic lupus erythematosus. II. Attempted detection by viral RNA-dependant DNA polymerase assay. Annals of the Rheumatic Diseases, 37, 225-233.

Phillips, P. E., Hargrave, R., Stewart, E., and Sarkar, N. H. (1976). Type $C$ oncornavirus isolation studies in systemic lupus erythematosus. I. Attempted detection by isopycnic sedimentation of ${ }^{3} \mathrm{H}$-uridine labelled virions. Annals of the Rheumatic Diseases, 35, 422-428.

Phillips, P. E., Sellers, S. A., and Cotronei, S. L. (1978). Type $\mathbf{C}$ oncornavirus isolation studies in systemic lupus erythematosus. III. Isolation of a putative retrovirus by triple cells fusion. Annals of the Rheumatic Diseases, 37, 254-237.

Prochownik, E. V., and Kirstein, W. H. (1976). Inhibition of reverse transcriptase of primate type-C viruses by $7 \mathrm{~S}$ immunoglobulin form patients with leukemia. Nature, 260, 64-67.

Rowe, W. P., Pugh, W. E., and Hartley, J. W. (1970). Plaque assay techniques for murine leukaemia viruses. Virology, 42, 1136-1139.

Schmidt, N. J., Lennette, E. H., Woodie, J. D., and Ho, H. H. (1966). Identification of rubella virus isolation by immunofluorescent staining, and a comparison of the sensitivity of three cell culture systems for recovery of virus. Journal of Laboratory and Clinical Medicine, 68, 502-509.

Seck, R., Wayne, A. B., and Desmet, G. (1970). La Lacticodeshydrogenase serique (LDH) et ses isoenzymes. Bulletin de la Société Médicale d'Afrique Noire de Langue Française, 15, 361-380.

Snyder, H. W., Pincus, T., and Fleissner, E. (1976). Specificities of human immunoglobulins reactive with antigens in preparations of several mammalian type-C viruses. Virology, 75, 60-73.

Spruance, S. L., Richards, O. C., Smith, C. B., and Ward, J. R. (1975). DNA polymerase activity of cultured rheumatoid synovial cells. Arthritis and Rheumatism, 18, 229-235.

Stephenson, J. R., and Aaronson, S. A. (1976). Search for antigens and antibodies cross-reactive with type-C viruses of the woolly monkey and gibbon ape in animal models and humans. Proceedings of the National Academy of Sciences of the USA, 73, 1725-1729.

Stephenson, J. R., Scolnick, E. M., and Aaronson, S. A. (1972). Genetic stability of the sarcoma viruses in murine and avian sarcoma virus-transformed nonproducer cells. International Journal of Cancer, 9, 577-583.

Stratton, J. A. (1972). Response of synovial fluid and peripheral blood lymphocytes to in vitro stimulation. Arthritis and Rheumatism, 15, 457.

Talal, N. (1978). Autoimmunity: Genetic, Immunologic, Virologic and Clinical Aspects. Academic Press: London.

Teich, N. M., Weiss, R. A., Salahuddin, S. Z., Gallagher, R. E., Gillespie, D. H., and Gallo, R. C. (1975). Infective transmission and characterization of a $\mathbf{C}$-type virus released by cultured human myeloid leukaemia cells. Nature, 256, 551-555.

Todaro, C. J., Sherr, C. J., Benveniste, R. E., Lieber, M. M., and Melnick, J. L. (1974). Type C viruses of baboons: isolation from normal cell cultures. Cell, 2, 55-61.

Wangel, A., and Klockars, M. (1977). Lymphocyte subpopulations in rheumatoid synovial tissue. Annals of the Rheumatic Diseases, 36, 176-180.

Yoshiki, T., Mellors, R. C., Hardy, W. D., Jr., and Fleissner, E. (1974). Common cell surface antigen associatited with mammalian C-type RNA viruses. Journal of Experimental Medicine, 139, 925-942. 